\title{
PROPOSAL FOR THE ASSESSMENT OF STEEL TRUSS RELIABILITY UNDER FIRE CONDITIONS
}

\begin{abstract}
K. KUBICKA ${ }^{1}$, U. RADOŃ ${ }^{2}$
The paper presents a proposal for the assessment of the reliability of steel truss (both statically determinate and indeterminate) in the persistent and accidental design situation. In the analysis, a probabilistic approach was used. The global Hasofer-Lind reliability index was employed, computed in successive time steps for the whole structure, not for individual elements. The statically determinate truss was modelled as a serial system from the reliability standpoint. For the statically indeterminate truss, kinematically admissible failure mechanisms were determined by means of the examination of the singularity of the stiffness matrix of the structure, converting the truss into a geometrically variable system. For the problem thus formulated, a serial-parallel reliability model was constructed. Monitoring the reliability index in the successive minutes of the fire makes it possible to estimate the probability of the structure failure, and to decide whether the required safety level is maintained.
\end{abstract}

Keywords: reliability, serial system, parallel system, fire analysis, Hasofer-Lind reliability index.

\section{INTRODUCTION}

The load bearing capacity of elements and structures designed in accordance with code recommendations is considered to be equivalent to the load bearing capacity of the weakest critical section, when only one failure mechanism is taken into account. The task becomes much more difficult when the structure is composed of many elements and different failure mechanisms may be involved. Then, the actual structure is substituted with an equivalent discrete system so that all kinematically admissible failure mechanisms could be accounted for. The structure is converted into a geometrically variable system.

\footnotetext{
${ }^{1}$ MSc., Kielce,University of Technology, Faculty of Civil Engineering and Architecture, Al. 1000-lecia PP 7 , 25-314 Kielce, Poland, e-mail: ksuckert@tu.kielce.pl

${ }^{2}$ DSc., Kielce, University of Technology, Faculty of Civil Engineering and Architecture, Al. 1000-lecia PP 7 , 25-314 Kielce, Poland, e-mail: zmbur@tu.kielce.pl
} 
As regards building structures, serial (structures, usually statically determinate, in which one failure mechanism is found), parallel and mixed systems are considered. The present study is an attempt at assessing the reliability of a steel structure by modelling the reliability both in regular operation, and also under fire conditions.

Steel structures are extremely sensitive to high temperatures, which is confirmed by fire analyses. With an increase in temperature of fire gases, steel mechanical properties, namely yield strength and modulus of elasticity are reduced, which leads directly to a decrease in the bearing capacity.

\section{DESIGN OF STEEL STRUCTURES UNDER FIRE CONDITIONS}

Steel is a widely used material in structures because of its advantageous properties, mainly mechanical ones. Steel, however, has some drawbacks. The major, the most serious one, is steel extremely low resistance to high temperatures. Steel substantial vulnerability to fire temperatures results from the fact that its properties significantly deteriorate with an increase in temperature. The most important mechanical properties of steel include yield strength and modulus of elasticity. Fig. 1 shows curves developed by various researches to describe changes in steel mechanical properties with an increase in temperature [1]. A decrease in the values of mechanical parameters leads directly to a reduction in the load bearing capacity, which finally results in the ultimate limit state being exceeded.
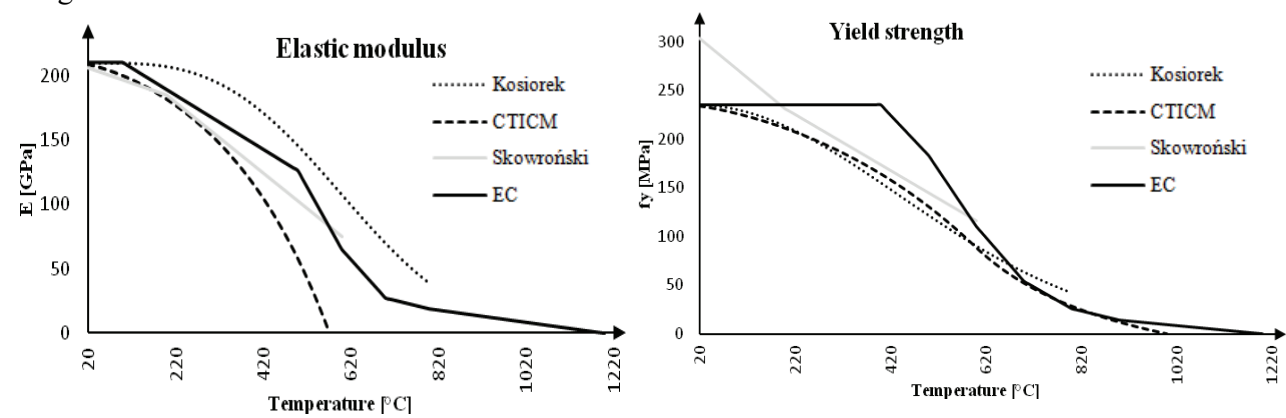

Fig.1. Mechanical properties of steel at fire temperatures.

The design of steel structures for fire conditions can be made in accordance with three methods, namely bearing capacity, temperature and time [Fig.2]. For each of these methods, it is necessary to know the temperature of fire gases, which is obtained from fire curves. When the temperature of 
fire gases is known, it is possible to determine the temperatures reached by individual bars, and then compare those with the critical temperature.

In the present study, the fire analysis was performed using the standard fire curve. The critical temperature, the temperature of insulated and uninsulated elements were calculated according to $[1,2]$.

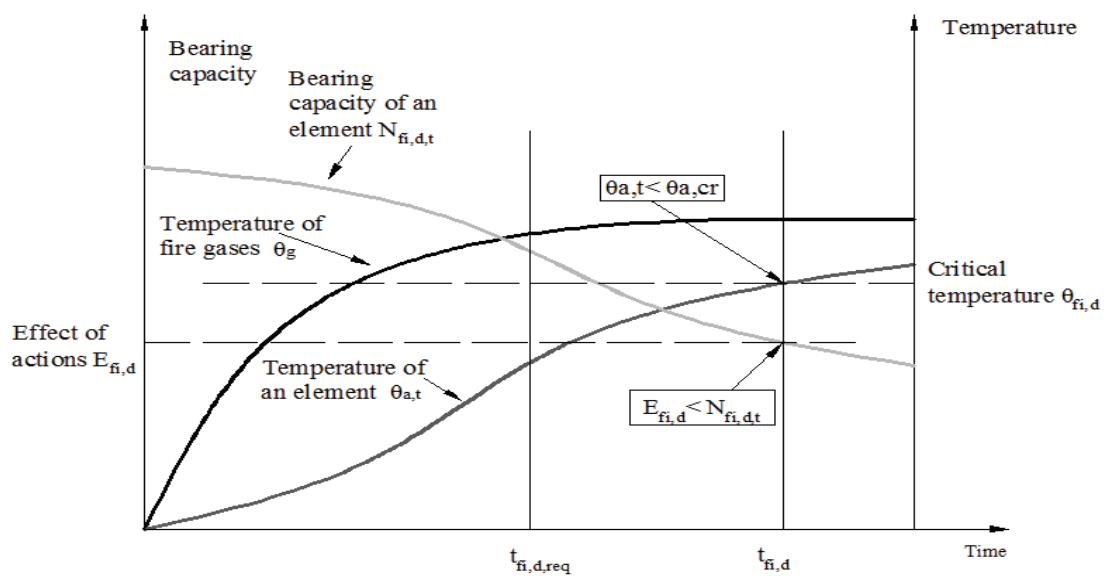

Fig.2. Methods of the fire analysis

For fire conditions, the formulas that allow the determination of forces produced in bars by loads become modified compared with the regular design. In trusses, which are analysed in the present study, only axial forces are generated, therefore the formulas that are provided are these for the bearing capacity of tension and compression elements. These values were calculated according to formulas from Eurocodes [1,3]. In fire analyses, not only the bearing capacity but also the effect of actions is reduced in accordance with [2].

\section{RELIABILITY ANALYSIS}

\subsection{RELIABILITY OF AN ELEMENT}

The reliability of an element $R(\omega)$ is defined as the probability that the bearing capacity of an element $\mathrm{N}(\omega)$ will be greater than the effect of actions $\mathrm{E}(\omega): R(\omega)=\operatorname{Pr}\{N(\omega)>E(\omega)\}$. It is assumed in the study that both the bearing capacity of an element and the effect of actions have normal 
distribution (Fig.3a) and are characterised by standard deviation $\left(\sigma_{\mathrm{E}}, \sigma_{\mathrm{N}}\right)$ and the expected value $\left(\mu_{\mathrm{E}}\right.$, $\left.\mu_{\mathrm{N}}\right)$. Value $\mu_{\mathrm{Z}}$, marked in Fig. 3a, is the expected value of the safety margin $Z(\omega)$, which is defined as follows: $Z(\omega)=N(\omega)-E(\omega)$

a)

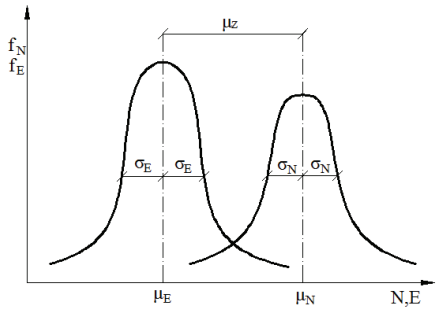

b)

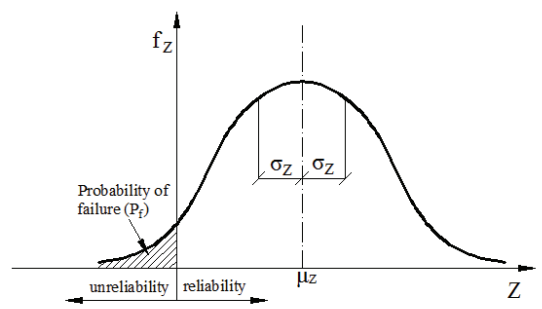

Fig.3. Distribution of the bearing capacity, of the effect of actions (a) and of the safety margin (b)

As it was assumed in the study that the bearing capacity and the effect of actions have normal distribution, the safety margin also has normal distribution. Thus, the expected value $\left(\mu_{Z}\right)$ and standard deviation $\left(\sigma_{Z}\right)$ of the safety margin and the reliability index for the i-th element can be expressed as follows: $\mu_{Z}=\mu_{N}-\mu_{E}, \sigma_{Z}=\sqrt{\sigma_{N}^{2}+\sigma_{E}^{2}}, t_{i}=\frac{\mu_{Z i}}{\sigma_{Z i}}$.

If the reliability index $t_{i}$ is known, it is possible to compute the probability of the element failure $\left(P_{f i}\right)$ and the reliability for a single element $\left(\mathrm{R}_{\mathrm{i}}\right): P_{f i}=\Phi\left(-t_{i}\right), R_{i}=1-P_{f i}$, where $\Phi(\cdot)$ - the Laplace function.

\subsection{RELIABILITY OF THE SYSTEM}

Three main models, namely serial, parallel and mixed, are used to evaluate the reliability of the system. The serial system is appropriate for structures that are statistically determinate. It should be noted that in the serial system, a failure of one element is equivalent to the failure of the whole structure. The reliability of structures, the static scheme of which is compliant with the serial system, is computed according to the formula [4]:

$$
R=\prod_{i=1}^{n} R_{i}=R_{1} R_{2} \ldots R_{n}
$$


The parallel system is appropriate for some structures that are statically indeterminate. In the parallel system, the structure remains reliable as long as at least one element is reliable. The reliability of the parallel system is computed as follows [4]:

$$
R=1-\prod_{j=1}^{m}\left(1-R_{j}\right)
$$

A majority of statically indeterminate structures is in line with mixed systems. The two basic systems are parallel-serial and serial-parallel. In real structures, however, mixed systems are usually more complicated. An example of the mixed system will be presented further in the paper.

\section{RELIABILITY ANALYSIS OF THE TRUSS UNDER FIRE CONDITION}

The presented method combines the fire and reliability analysis. The fire analysis was carried out according to the method described in [1,3]. The temperatures of fire gases and elements were calculated in the deterministic way. The influence of randomness was taken into consideration in the bearing capacity and the effect of actions. For both values, appropriate standard deviation was assumed. The structures were loaded only by the dead load $\left(\mathrm{P}_{\mathrm{k}}\right)$. It is assumed that coefficient of variation is $v_{E}=0,06[5]$, which gives $\sigma_{E}=0,06 P_{k}$.

The bearing capacity depends on a few factors, where yield strength $\left(f_{y}\right)$ and area of cross-section (A) were assumed to be random with coefficients of variation $v_{f_{y}}=0,08$ and $v_{A}=0,06$ according to [5]. The remaining parameters were treated as deterministic. Thus, the coefficient of variation for bearing capacity $(\mathrm{N})$ is defined as follows: $v_{N}=\sqrt{v_{f_{y}}^{2}+v_{A}^{2}}=\sqrt{0,08^{2}+0,06^{2}}=0,1$.

The reliability analysis was carried out according to the method presented in Chapter 3 .

The entrance data were the mean values of the effect of actions and the bearing capacity, which was calculated according to [1]. Then, the reliability for each element of the structure was calculated [Table 1].

In this way, the reliability of the whole structure was determined (highlighted $\mathbf{R}$ ). This value was calculated in different way for the statically determinate and indeterminate truss, which will be described in the following part of the paper. 
Table 1 . Reliability analysis of structures.

\begin{tabular}{|c|c|c|c|c|c|c|c|c|c|}
\hline 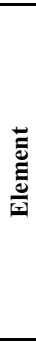 & 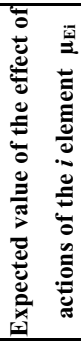 & 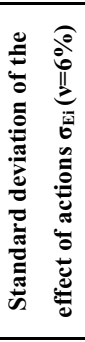 & 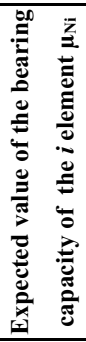 & 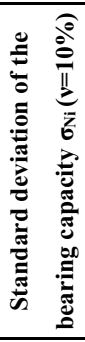 & 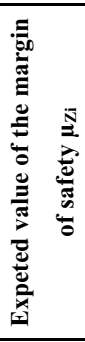 & 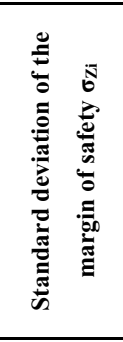 & $\frac{i \bar{v}}{\stackrel{0}{N}}$ & 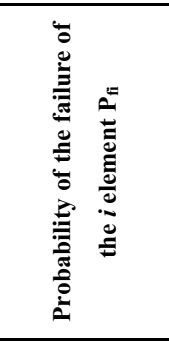 & 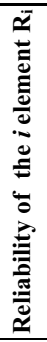 \\
\hline 1 & $E_{1}$ & $E_{1} \cdot 0.06$ & $\mathrm{~N}_{1}$ & $\mathrm{~N}_{1} \cdot 0.1$ & $\mathrm{~N}_{1}-\mathrm{E}_{1}$ & $\sqrt{\sigma_{E_{1}}^{2}+\sigma_{N_{1}}^{2}}$ & $\frac{\mu_{Z i}}{\sigma_{Z i}}$ & $\Phi\left(-t_{1}\right)$ & $1-\mathrm{P}_{1}$ \\
\hline . & · & . & . & . & . & . & . & . & \\
\hline $\mathrm{i}$ & $\mathrm{E}_{\mathrm{i}}$ & $E_{i} \cdot 0.06$ & $\mathrm{~N}_{\mathrm{i}}$ & $\mathrm{N}_{\mathrm{i}} \cdot 0.1$ & $\mathrm{~N}_{\mathrm{i}}-\mathrm{E}_{\mathrm{i}}$ & $\sqrt{\sigma_{E_{i}}^{2}+\sigma_{N_{i}}^{2}}$ & $\frac{\mu_{Z i}}{\sigma_{Z i}}$ & $\Phi\left(-t_{i}\right)$ & $1-P_{i}$ \\
\hline \multicolumn{8}{|c|}{ Probability of the failure of truss $\mathrm{p}_{\mathrm{f}}$} & $p_{f}=1-R$ & $\mathbf{R}$ \\
\hline \multicolumn{8}{|c|}{ Reliability index $\beta$} & $\beta=-\Phi^{-1}\left(p_{f}\right)$ & \\
\hline
\end{tabular}

\subsection{RELIABILITY ANALYSIS OF THE STATICALLY DETERMINATE TRUSS}

The analysis was carried out for the truss presented in Figure 4. In the table, the profiles of elements and the effect of actions are shown, where (-) means compression. All elements were assumed to be made from S275 steel. The only load was the dead load $\mathrm{p}=3 \mathrm{kN} / \mathrm{m}$ applied to the top flange, and it was converted to concentrated forces in the nodes.

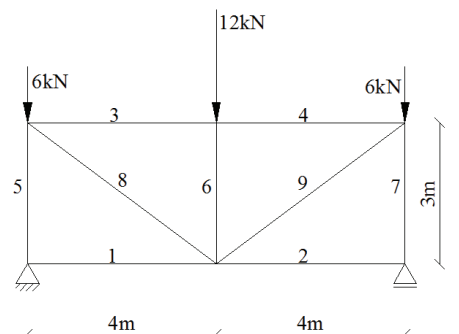

\begin{tabular}{|l|l|l|l|l|l|l|l|l|l|}
\hline Element & $\mathbf{1}$ & $\mathbf{2}$ & $\mathbf{3}$ & $\mathbf{4}$ & $\mathbf{5}$ & $\mathbf{6}$ & $\mathbf{7}$ & $\mathbf{8}$ & $\mathbf{9}$ \\
\hline Profiles & I 80 & I 100 & RO $44.5 \times 5$ & \multicolumn{2}{|l|}{ RO 20x2.3 } \\
\hline $\begin{array}{l}\text { Effect of } \\
\text { actions } \\
{[\mathbf{k N}]}\end{array}$ & 0 & -8 & -12 & & 10 & \\
\hline
\end{tabular}

Fig.4. Statically determinate steel truss.

The thermal analysis was carried out for insulated and uninsulated structure. All the elements were assumed to be heated from each side. In a fire, the compressed elements are the most threatened with the bearing capacity loss. The figures below present the results for the top flange elements [Fig.5a] and the posts [Fig.5b]. Grey lines represent the analysis results for the uninsulated 
structure, whereas the black ones show those for the insulated one. Solid lines indicate temperatures of the elements, and the dotted ones mark the critical temperature. Spray-applied mineral fibre with the thickness of $1.5 \mathrm{~cm}$ was assumed as an insulation. This material is characterized by the following parameters: density $\rho_{\mathrm{p}}=800 \mathrm{~kg} / \mathrm{m}^{3}$, specific heat $c_{\mathrm{p}}=1700 \mathrm{~J} /(\mathrm{kgK})$, thermal conductivity $\lambda_{\mathrm{p}}=0.2 \mathrm{~W} /(\mathrm{mK})$. As shown in the analysis, in the structure without insulation, the bearing capacity was exceeded in the seventh minute for the top flange elements, and in the ninth minute for the posts, so it was impossible to determine the critical temperature in successive minutes.

a)

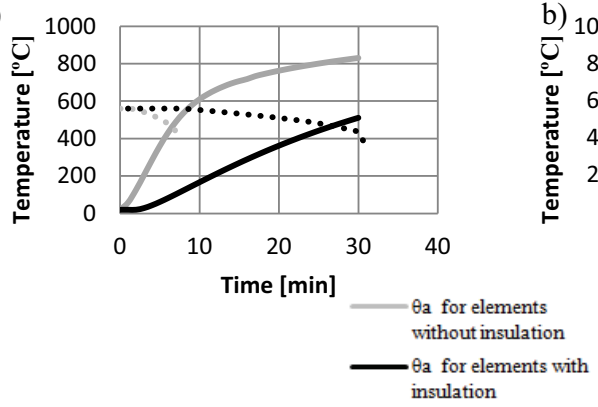

b) 1000

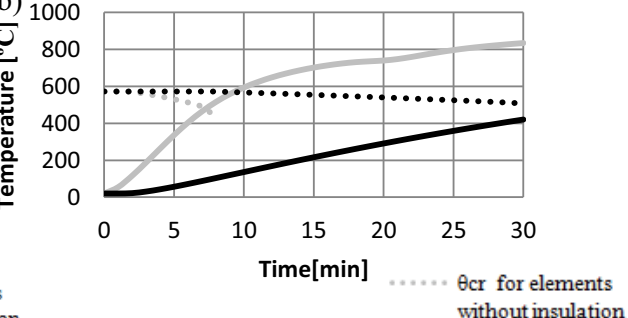

..... $\theta$ cr for elements

with insulation

Fig.5. Temperature analysis of compressed elements: a) elements of the top flange $(3,4), b)$ posts $(5,6,7)$

In the next part of analysis, for each step: $0,5,10,15,20,25$ and 30 minutes, the reliability analysis was carried out. The truss has statically determinate scheme and corresponds to the serial system, consequently, the failure of any element (1-9) results in the failure of the whole structure. The reliability of the structure $(\mathbf{R})$ is calculated according to equation (3.1), particularly:

$$
R=\prod_{i=1}^{9} R_{i}=R_{1} \cdot R_{2} \cdot R_{3} \cdot R_{4} \cdot R_{5} \cdot R_{6} \cdot R_{7} \cdot R_{8} \cdot R_{9}
$$

The results of the reliability analysis are presented in Fig. 6 . The required value of the reliability index $(\beta)$ was assumed, according to [6], to equal 1.34.

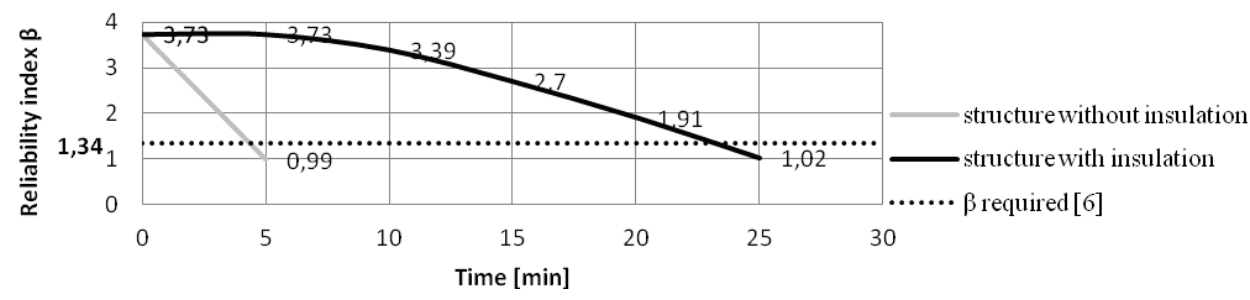

Fig.6. Monitoring the reliability index for statically determinate truss in successive minutes of the fire 
The thermal analysis of single elements indicates that the failure of uninsulated truss will occur as a result of exceeding critical temperature by compressed elements after 5 minutes. The reliability analysis of the truss as a whole structure points out that the structure without insulation is unreliable before the fifth minute. In addition, a decrease in the reliability index in this case is very rapid.

The thermal analysis of elements of insulated truss indicates that the failure occurs after 25 minutes as a result of exceeding the critical temperature by the elements of the top flange. The reliability analysis shows that structure will be safe for less than 25 minutes.

\subsection{RELIABILITY ANALYSIS OF THE STATICALLY INDETERMINATE TRUSS}

The following part presents the analysis of the indeterminate truss that is shown in Fig.7.

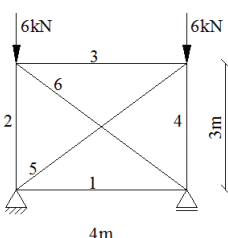

\begin{tabular}{|l|l|l|l|}
\hline Element & $\mathbf{1 , 3}$ & $\mathbf{2 , 4}$ & $\mathbf{5 , 6}$ \\
\hline Profiles (Truss "A") & I 80 & RO 33.7x3.6 & RO 30x3.2 \\
\hline Profiles (Truss "B") & RO 33.7x4 & RO 33.7x4 & RO 33.7x4 \\
\hline Effect of actions [kN] & 1.00 & -5.25 & -1.25 \\
\hline
\end{tabular}

Fig.7. Statically indeterminate truss

Basic assumptions are the same as in the case of the statically determinate truss. For the analyzed truss, the mixed system is appropriate. In such a system, kinematically admissible failure mechanisms (KAFM) must be defined. The first KAFM and its system diagram are shown in Fig. 8 . This KAFM represents situations when the structure failure occurs as the result of the failure of both cross-braces $(5,6)$. The reliability for this mechanism $\left(R_{I}\right)$ is calculated as for the parallel system (3.2).
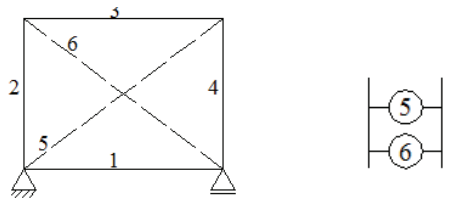

$$
R_{I}=1-\left(1-R_{5}\right)\left(1-R_{6}\right)
$$

Fig.8. I kinematically admissible failure mechanism for the statically indeterminate truss 
In the II KAFM (Fig.9), the structure failure results from the failure of one of cross braces $(5,6)$ and one of the elements 1-4. Consequently, reliability is calculated in two steps, first serial $\left(\mathrm{R}_{\text {IIA }} \cdot \mathrm{R}_{\mathrm{IIB}}\right)$, and then parallel $\left(\mathrm{R}_{\mathrm{II}}\right)$.
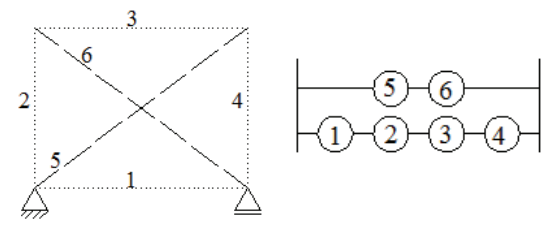

$$
\begin{gathered}
R_{I I A}=R_{5} \cdot R_{6} \\
R_{I I B}=R_{1} \cdot R_{2} \cdot R_{3} \cdot R_{4} \\
R_{I I}=1-\left(1-R_{I I A}\right)\left(1-R_{I I B}\right)
\end{gathered}
$$

Fig.9. II kinematically admissible failure mechanism for the statically indeterminate truss

The last III KAFM (Fig.10) represents the structure failure due to the failure of any pair of elements 1-4. The reliability for this mechanism is calculated as for the parallel-serial system in the way shown below.
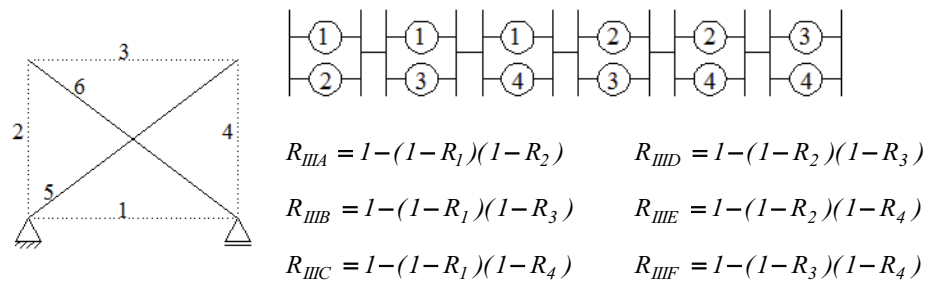

$$
R_{\text {III }}=R_{\text {IIIA }} \cdot R_{\text {IIIB }} \cdot R_{\text {IIIC }} \cdot R_{\text {IIID }} \cdot R_{\text {IIIE }} \cdot R_{\text {IIIF }}
$$

Fig.10. III kinematically admissible failure mechanism for the statically indeterminate truss.

When reliabilities for I-III KAFM $\left(\mathrm{R}_{\mathrm{I}}, \mathrm{R}_{\mathrm{II}}, \mathrm{R}_{\mathrm{III}}\right)$ are known, the reliability of the whole truss is calculated as follows:

$$
R=R_{I} \cdot R_{I I} \cdot R_{I I I}
$$

because all KAFMs are connected in a serial way.

The reliability analysis of the statically indeterminate truss under fire condition was carried out in accordance with the method presented above. The results are shown in Fig.13. 


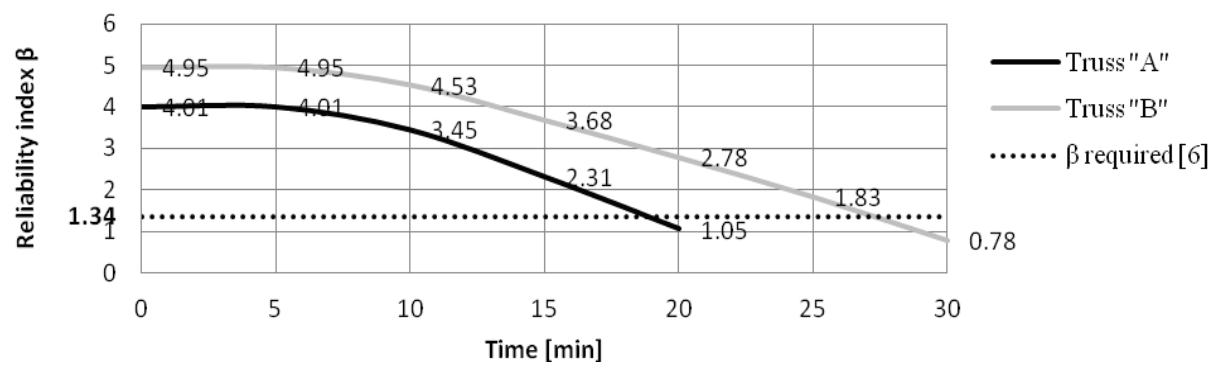

Fig.11. Monitoring the reliability index for the statically indeterminate truss in successive minutes of the fire

As can be seen in Table 2, truss "B" achieved better results than truss "A". In the table, reliability indexes for single elements of the truss in the persistent design situation are shown. In this case, the required reliability index is equal to 3.8 .

Table 2. Reliability index for a single element in the persistent design situation.

\begin{tabular}{|c|c|c|c|}
\hline \multirow{2}{*}{ TRUSS } & \multicolumn{3}{|c|}{ ELEMENT } \\
\cline { 2 - 4 } & $\mathbf{1 , 3}$ & $\mathbf{2 , 4}$ & $\mathbf{5 , 6}$ \\
\hline Truss "A" & 9.95 & 2.77 & 2.92 \\
\hline Truss "B" & 9.9 & 3.23 & 5.83 \\
\hline
\end{tabular}

The compressed elements of truss "A" had reliability indexes lower than 3. During the fire analysis, reliability indexes are reduced as a result of a decrease in the bearing capacity, so under fire conditions, truss "A" dropped below the required value of the reliability index relatively fast. Truss "B" stayed safe longer, because reliability indexes of single elements were higher. To ensure greater safety, the profile of posts (elements 2,4 ) should be extended to reach the reliability index higher than 3.8 . 


\section{CONCLUSIONS}

The reliability of the structure depends on the random variability of the effect of actions, the bearing capacity of each element being a component of the system, and primarily on the description of the reliability structure. In the persistent design situation, for the construction solution involving lattice truss in the form of statically indeterminate truss, a substantially much higher reliability index was obtained than it was the case for the statically determinate truss.

Structural design which utilizes the ultimate limit state method with partial safety factors, without taking into account the reliability structure may lead to errors in evaluating the reliability of a given building structure.

In the literature, the probabilistic measure of safety for the fire conditions is the minimum safety factor computed for the main structural elements at the ultimate limit state.

The present study is a proposal for the assessment of the reliability of a steel structure by modelling reliability structures both in the persistent design situation and also for fire conditions.

Monitoring the reliability index in successive minutes of the fire duration makes it possible to estimate the probability of the structure failure and to decide whether the required safety level is maintained.

When making calculations for kinematically admissible failure mechanisms, it is necessary to obtain a realistic representation of how a structure will behave in a fire.

\section{REFERENCES}

1. PN-EN 1993-1-2 Eurocode 3: Design of steel structures. Part 1-2: General rules - Structural fire design

2. PN-EN 1991-1-2 Eurocode 1: Action on structures. Part 1-2: General actions - Action on structures exposed to fire.

3. PN-EN 1993-1-1 Eurocode 3: Design of steel structures. Part 1-1: General rules and rules for buildings.

4. Gwóźdź M., Machowski A., The selected studies and calculations of building structures by probabilistic methods, Politechnika Krakowska, Kraków, 2011 [in Polish]

5. Maślak M., The fire durability of steel bar structures, Politechnika Krakowska, Kraków, 2008 [in Polish]

6. Maślak M., Assessment of the fire safety level ensured by a steel load-bearing structure when subjected to a fire, Eighth International Conference on Advances in Steel Structures, Lisbon, Portugal, July 22-24, 2015 (post conference materials on pen-drive, 15 pages). 


\section{LIST OF FIGURES AND TABLES}

Fig. 1. Mechanical properties of steel at fire temperatures.

Rys. 1. Właściwości mechaniczne stali w temperaturach pożarowych

Fig. 2. Methods of the fire analysis

Rys. 2. Metody analizy pożarowej

Fig. 3. Distribution of the bearing capacity, of the effect of actions (a) and of the safety margin (b)

Rys. 3. Rozkład nośności i efektu oddziaływań (a) oraz marginesu bezpieczeństwa (b)

Tab.1. Reliability analysis of structures.

Tab.1. Analiza niezawodnościowa konstrukcji

Fig.4. Statically determinate steel truss.

Rys.4. Statycznie wyznaczalna stalowa kratownica.

Fig.5. Temperature analysis of compressed elements: a) elements of the top flange $(3,4)$, b) posts $(5,6,7)$

Rys.5. Analiza temperaturowa ściskanych elementów: a) półki górnej $(3,4)$, b) słupków $(5,6,7)$

Fig.6. Monitoring the reliability index for the statically determinate truss in successive minutes of the fire Rys.6. Śledzenie wskaźnika niezawodności dla statycznie wyznaczalnej kratownicy w kolejnych minutach pożaru

Fig.7. Statically indeterminate truss

Rys.7. Statycznie niewyznaczalna kratownica

Fig.8. I kinematically admissible failure mechanism for statically indeterminate truss

Rys.8. I kinematycznie dopuszczalny mechanizm zniszczenia dla statycznie niewyznaczalnej kratownicy

Fig.9. II kinematically admissible failure mechanism for statically indeterminate truss

Rys.9. II kinematycznie dopuszczalny mechanizm zniszczenia dla statycznie niewyznaczalnej kratownicy

Fig.10. III kinematically admissible failure mechanism for statically indeterminate truss

Rys.10. III kinematycznie dopuszczalny mechanizm zniszczenia dla statycznie niewyznaczalnej kratownicy

Fig.11. Monitoring the reliability index for the statically indeterminate truss in successive minutes of the fire Rys.11. Śledzenie wskaźnika niezawodności dla statycznie niewyznaczalnej kratownicy w kolejnych minutach pożaru 


\title{
PROPOZYCJA OCENY NIEZAWODNOŚCI STALOWEJ KRATOWNICY W WARUNKACH POŻAROWYCH
}

\author{
Słowa kluczowe: niezawodność, system szeregowy, system równoległy, analiza pożarowa, wskaźnik niezawodności \\ Hasofera-Linda
}

Artykuł przedstawia propozycję oceny niezawodności stalowej kratownicy (statycznie wyznaczalnej i niewyznaczalnej) w podstawowej i wyjątkowej sytuacji projektowej. W analizie zastosowano podejście probabilistyczne z globalnym wskaźnikiem niezawodności Hasofera-Linda obliczanym w kolejnych krokach czasowych dla konstrukcji jako całości, a nie poszczególnych elementów. Kratownica statycznie wyznaczalna została zamodelowana jako układ szeregowy z punktu widzenia niezawodności. Dla kratownicy statycznie niewyznaczalnej poprzez badanie osobliwości macierzy sztywności konstrukcji określono kinematycznie dopuszczalne mechanizmy zniszczenia, przekształcające ją w układ geometrycznie zmienny. Dla tak postawionego zadania zbudowano szeregowo-równoległy model niezawodnościowy. Stal jest materiałem chętnie wykorzystywanym w budownictwie ze względu na szereg korzystnych właściwości, głównie mechanicznych. Niemniej jednak nie jest to materiał pozbawiony wad. Główną, najpoważniejszą jest wyjątkowo niska odporność na wysokie temperatury. Wraz ze wzrostem temperatury gazów pożarowych właściwości mechaniczne stali: granica plastyczności i moduł sprężystości ulegają redukcji co w bezpośredni sposób przekłada się na spadek nośności.

Projektowanie konstrukcji stalowych w warunkach pożaru może być przeprowadzane według trzech metod: nośności, temperatury, czasu. W każdej z tych metod musi być znana temperatura gazów pożarowych, którą określa się korzystając z krzywych pożarowych. W pracy analiza pożarowa została przeprowadzona przy przyjęciu standardowej krzywej pożarowej. Znając temperaturę gazów pożarowych, można określić temperaturę jaką osiągają poszczególne pręty, a następnie porównać ją z temperaturą krytyczną. Takie podejście umożliwia sprawdzenie konstrukcji w dziedzinie czasu. Ponadto znajomość zmiany temperatury w elementach pozwala stwierdzić czy istnieje konieczność uwzględniania zmian dotyczących właściwości mechanicznych stali. W sytuacji pożaru wzory pozwalające określić nośność elementów rozciąganych i ściskanych ulegają modyfikacji w stosunku do podstawowej sytuacji projektowej.

Metoda przedstawiona w artykule łączy analizę pożarową i niezawodnościową. Analiza pożarowa została przeprowadzona według procedur opisanych w Eurokodach. Temperatura gazów i elementów została obliczona w sposób deterministyczny. Losowe parametry zostały uwzględnione podczas obliczania nośności i efektów oddziaływań. W pracy założono, że zarówno nośność elementu, jak i efekt oddziaływań mają rozkład normalny i są charakteryzowane poprzez odchylenie standardowe $\left(\sigma_{\mathrm{E}}, \sigma_{\mathrm{N}}\right)$ i wartość oczekiwaną $\left(\mu_{\mathrm{E}}, \mu_{\mathrm{N}}\right)$.. Konstrukcja była obciążona jedynie obciążeniem stałym o wartości $\mathrm{p}=3 \mathrm{kN} / \mathrm{m}$, przyłożonym do górnego pasa i sprowadzonym do sił skupionych $\mathrm{w}$ węzłach. Nośność jest funkcją granicy plastyczności i pola przekroju poprzecznego, które w pracy potraktowano jako wielkości losowe. Pozostałe parametry traktowano jako deterministyczne. W pracy przeanalizowano dwa rodzaje kratownic: statycznie wyznaczalną i niewyznaczalną. Niezawodność dla obu typów kratownic była liczona w różny sposób w zależności od przyjętego modelu niezawodnościowego. Założono, że wszystkie elementy wykonano ze stali S275. Analizę termiczną przeprowadzono dla izolowanych i nieizolowanych prętów konstrukcji. Założono, że wszystkie elementy są ogrzewane z każdej strony. Jako izolację przyjęto natryskowe włókno mineralne o grubości 1,5 $\mathrm{cm}$. 
Analiza niezawodnościowa została przeprowadzona w kolejnych minutach pożaru: $0,5,10,15,20,25$ i 30 . Statycznie wyznaczalnej kratownicy odpowiada system szeregowy, podczas gdy dla statycznie niewyznaczalnej kratownicy odpowiedni jest system mieszany. W przypadku tego systemu pojawia się konieczność określenia kinematycznie dopuszczalnego mechanizmu zniszczenia (KDMZ). Dla analizowanej kratownicy zidentyfikowano trzy typy KDMZ: równoległy (I KDMZ), szeregowo-równoległy (II KDMZ) i równoległo-szeregowy (III KDMZ). Wszystkie KDMZ są ze sobą połączone w sposób szeregowy.

Przeprowadzona analiza wykazuje, że projektowanie konstrukcji przy wykorzystaniu metody stanów granicznych z częściowymi współczynnikami bezpieczeństwa, bez uwzględnienia struktury niezawodnościowej może prowadzić do błędów w określaniu jej niezawodności. Przedstawiona praca jest propozycją oceny niezawodności konstrukcji stalowej jako całości w trwałej sytuacji projektowej oraz w warunkach pożarowych. Monitorowanie wskaźnika niezawodności w kolejnych minutach trwania pożaru umożliwiło oszacowanie prawdopodobieństwa zniszczenia i zadecydowanie czy wymagany poziom bezpieczeństwa jest zapewniony. 